\author{
The Origins of France \\ From Clovis to the Capetians, 500-1000
}


NEW STUDIES IN MEDIEVAL HISTORY

General Editor: Maurice Keen

PUBLISHED

Roger Collins

EARLY MEDIEVAL SPAIN

Unity in Diversity 400-1000 (Second edition)

Alan Forey

THE MILITARY ORDERS FROM THE

TWELFTH TO THE EARLY FOURTEENTH CENTURIES

Michael Haren

MEDIEVAL THOUGHT

The Western Intellectual Tradition from Antiquity

to the Thirteenth Century (Second edition)

Edward James

THE ORIGINS OF FRANCE

From Clovis to the Capetians 500-1000

Angus McKay

SPAIN IN THE MIDDLE AGES

From Frontier to Empire, 1000-1500

David Potter

A HISTORY OF FRANCE 1460-1560

The Emergence of a Nation State

Michael Richter

MEDIEVAL IRELAND

The Enduring Tradition

Mark Whittow

THE MAKING OF ORTHODOX BYZANTIUM, 600-1025

FORTHCOMING

Jeremy Johns

EARLY MEDIEVAL SICILY

Continuity and Change from the Vandals

to Frederick II, $450-1250$ 


\title{
The Origins of France
}

From Clovis to the Capetians, 500-1000

\author{
EDWARD JAMES
}

To the Memory of Denis Bethell,

15 January 1934 - 15 February 1981

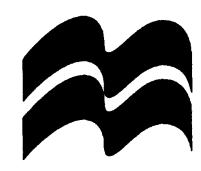


(C) Edward James 1982

All rights reserved. No reproduction, copy or transmission of this publication may be made without written permission.

No paragraph of this publication may be reproduced, copied or transmitted save with written permission or in accordance with the provisions of the Copyright, Designs and Patents Act 1988, or under the terms of any licence permitting limited copying issued by the Copyright Licensing Agency, 90 Tottenham Court Road, London W1P 9HE.

Any person who does any unauthorised act in relation to this publication may be liable to criminal prosecution and civil claims for damages.

First published 1982 by

MACMILLAN PRESS LTD

Houndmills, Basingstoke, Hampshire RG21 6XS

and London

Companies and representatives

throughout the world

ISBN 978-0-333-27052-3 ISBN 978-1-349-16954-2 (eBook)

DOI 10.1007/978-1-349-16954-2

A catalogue record for this book is available from the British Library.

This book is printed on paper suitable for recycling and made from fully managed and sustained forest sources.

$\begin{array}{lllllll}14 & 13 & 12 & 11 & 10 & 9 & 8\end{array}$

$\begin{array}{lllll}04 & 03 & 02 & 01 & 00\end{array}$ 


\section{Contents}

Acknowledgements vii

Chronological Table ix

The Civitates of Gaul, c.600 xiii

Maps xviii

INTRODUCTION 1

\section{PART I: COMMUNITY}

1 The Peoples of GaUl 13

$\begin{array}{ll}\text { The South-West } & 15\end{array}$

The South-East $\quad 21$

The North 26

2 Cities And Towns 43

Bishops and Counts in the Merovingian Civitas 49

Lords and Men in the Carolingian Town 63

3 FAMILY, KIN AND LAW 73

4. The Christian Community 93

Christians and Pagans $\quad 93$

Christians and Jews 101

The Monastic Community 105

\section{PART II: AUTHORITY}

INTRODUCTION: KINGS AND ARISTROCRATS 123

5 ThE MEROVINGIAN SUPREMACY 127

6. MAYORS AND PRINCES 145

7. THE CAROLINGIAN EXPERIMENT 157

8. THE FRAGMENTATION OF GAUL 171

Gaul around the Year $1000 \quad 187$

9. BISHOPS AND COUNCILS 197

Abbreviations $\quad 209$

Bibliographies $\quad 209$

A. Works in English $\quad 210$

B. Works in Other Languages $\quad 220$

References 231

Genealogical Tables $\quad 237$

Index $\quad 241$ 


\section{LIST OF MAPS}

Map 1 Gaul in the Fifth Century

Map 2 The Civitates of Sixth-century Gaul: The North

Map 3 The Civitates of Sixth-century Gaul: The South

Map 4 The Monasteries of Frankish Gaul

Map 5 The Partitions of the Ninth Century

Map 6 Gaul around the year 1000

\section{List Of Plates}

1 A nineteenth-century impression of the treasure found in the grave of King Childeric (d 481/2) at Tournai in 1653. Courtesy; the Bodleian Library, Oxford

2 The ivory belt-buckle reputedly worn by St Caesarius of Arles

3 The front and back of the gravestone from Niederdollendorf.

4 Two of the incised stone slabs from the funerary chapel of Abbot Mellebaudis at Poitiers (c. 700)

5 The text of laws 26-28 in the earliest surviving manuscript of the Lex Salica. Courtesy: the Ducal Library, Wolfenbüttel

6 A contemporary portrait of Louis the Pious incorporating the text of a poem

7 The reading-desk which may once have been used by St Radegund

8 A seventeenth-century engraving of an early drawing of the great Carolingian monastery of Centula or St-Riquier 


\section{Acknowledgements}

This book is dedicated to the man to whom it owes the most, Denis Bethell, the founder of the series 'New Studies in Medieval History'. He invited me to write it, spent very many hours discussing it with me, and, before his tragically early death, had read and commented on the first half, in his capacity as General Editor. His contribution was more than that, however. In the eight years during which he was my colleague in the Department of Medieval History at University College Dublin, I learnt from him more about my subject, and about the art of teaching, than I have from anyone else. He will always be missed by those who knew his wit, humanity and great erudition.

I am also most grateful to Michael Richter, from whom I learnt much when we lectured together on the Merovingians and Carolingians at UCD; to Clare Hall, Cambridge, for making me an associate in 1977, when I was beginning work on the book, and to UCD for helping to finance that stay in Cambridge; to Helen Humphreys, of the York Archaeological Trust, for drawing the maps; to Maurice Keen, and above all to those kind friends who have read through the final draft with great care and perception, and whose advice I have not always followed: Richard Fletcher, Rosamond McKitterick, Patricia McNulty, Ian Wood, and my wife Columba. In a happier year this book would have been dedicated to her, for without her support and assistance it would have been impossible.

York

October 1981 


\section{Chronological Table}

406

418

443

466-84

475

476

481?-511?

486

507

507-11

516

534

536

542

558

561

575

584

587

591

599

613

615

623

629-38

641

642

$657664 / 5$

660 ?

673-5

676
The 'Great Invasion' of Vandals, Alans, Sueves and Burgundians across the Rhine

Visigoths settled in Aquitaine

Burgundians settled in Sapaudia

Euric king of the Visigoths

Auvergne ceded to Euric

Last Roman Emperor in the West deposed

Clovis king of the Franks

Clovis defeats Syagrius, 'king of the Romans'

Clovis defeats Visigoths at Vouillé

Pactus Legis Salicae drawn up

Death of King Gundobad of the Burgundians

Frankish conquest of Burgundy

Provence ceded to Franks by Ostrogoths

Death of Caesarius of Arles. Bubonic plague reaches Gaul

Chlothar I sole king of the Franks

Partition of kingdom among Chlothar's four sons

Sigibert assassinated

Chilperic assassinated

Treaty of Andelot between Guntram, Brunhild and Childebert II

End of Gregory of Tours' History

Defeat of Chilperic's son Chlothar II by Childebert's sons

Chlothar II sole king of the Franks; death of Brunhild; Edict of Paris

Death of St Columbanus

Chlothar makes son Dagobert king in Austrasia

Dagobert I sole king of the Franks

Pippin I's son Grimoald becomes mayor of the

Austrasian palace

End of Fredegar's Chronicle

Regency of Balthild in Neustria

Grimoald exiles King Dagobert II to Ireland

Childeric II sole king of the Franks

Dagobert II recalled from Ireland 
Ebroin, mayor, has St Leger killed

Ebroin defeats Austrasians under Pippin II;

Ebroin assassinated

Pippin defeats Neustrians at Tertry; establishes

Theuderic III as sole Frankish king

Death of Pippin II

Charles Martel chooses own king

Eudo defeats Al-Samh ibn Malik outside

Toulouse

Charles Martel defeats 'Abd ar-Rahman near

Poitiers

Death of Eudo; Charles Martel campaigns in Aquitaine

Charles Martel succeeded by Carloman and Pippin

Carloman becomes monk in Rome

Pippin king of the Franks

St Boniface martyred in Frisia

Waifar defeated in Aquitaine; Pippin succeeded by Charlemagne and Carloman

Death of Carloman

Charlemagne crowned king of the Lombards Charlemagne's army defeated by Basques at Roncesvalles; death of Roland Louis King in Aquitaine; Pippin in Italy Admonitio Generalis Revolt of Pippin against Charlemagne Charlemagne crowned Emperor in Rome Death of Alcuin

Louis the Pious succeeds Charlemagne Ordinatio Imperii

Death of Bernard of Italy

Death of Benedict of Aniane

Penance of Louis at Attigny

Birth of Charles the Bald

Lothar revolts against father Louis

Lothar declares self sole master of Empire

Restoration of Louis

Pippin I of Aquitaine dies

Death of Louis the Pious 
843

844

848

855

858

864

869

875

877

879

882

884

885-6

888

890

898

901

905

910

911

919

922

923

929

936

942

943

954

956

960

962

978

986

987

992

993

Treaty of Verdun

Vikings raid up Garonne as far as Toulouse

Charles the Bald crowned at Orleans

Partition of Lothar I's Middle Kingdom

Louis the German invades West Francia

Pippin II of Aquitaine forced into monastery

Charles the Bald crowned at Metz

Charles crowned Emperor in Rome

Louis II succeeds Charles the Bald

Boso declared king at Mantaille

Hincmar of Rheims flees from Vikings; dies

Charles III 'the Fat' elected king of West Francia

Siege of Paris by the Vikings

Odo king in West Francia; Rudolf in Burgundy

Louis, son of Boso, king in Provence

Charles III 'the Simple' succeeds Odo

Louis of Provence Emperor

Louis blinded by Berengar of Friuli

Foundation of Cluny by William of Aquitaine

Treaty between Charles III and Rollo of

Normandy

Much of Brittany falls to Vikings

Revolt against Charles III: Robert crowned king

Robert's son-in-law Ralph succeeds; Charles III imprisoned by Herbert of Vermandois

Death of Charles III

Death of Ralph; Charles III's son Louis brought from England and crowned

William Longsword of Normandy assassinated

Death of Herbert of Vermandois

Louis IV succeeded by Lothar

Death of Hugh 'the Great'

Hugh Capet made 'duke of the Franks'; his

brother Odo duke of Burgundy

The Saxon Otto I crowned Emperor in Rome

Lothar's invasion of Lotharingia

Louis V succeeds Lothar

Death of Louis V; Hugh Capet crowned

Death of Charles of Lorraine

Rudolf III 'the Sluggard' succeeds Conrad 'the 


\section{CHRONOLOGICAL TABLE}

996

Peaceful' (937-993) as king in Burgundy

999 Robert II'the Pious' succeeds Hugh Capet Gerbert of Aurillac becomes Pope Sylvester II 


\section{The Civitates of Gaul, c. 600 (Key to Maps 2 and 3)}

The civitates are grouped into the ecclesiastical provinces of the late sixth century; but the provincial names, the form of the city names, and the order in which they are listed are taken from the fifth-century list of cities, the Notitia Galliarum. The Latin name for the town is followed by the modern town name and, where appropriate, the name of the modern province which corresponds to the old civitas. As in the rest of the book, the modern spellings are followed except in the cases of Köln , Lyon, Marseille and Reims, where the traditional English forms are used. If there are two modern town names, this normally indicates a shift of the civitas-capital.

\section{A. Lugdunensis Prima}

1. Metropolis civitas Lugdunensium: Lyons

2. Civitas Aeduorum (Augustodunum): Autun

3. Civitas Lingonum: Langres

4. Castrum Cabillonense: Chalon-sur-Saône

5. Castrum Matisconense: Mâcon

\section{B. Lugdunensis Secunda}

1. Metropolis civitas Rotomagensium: Rouen

2. Civitas Baiocassium: Bayeux (Bessin)

3. Civitas Abrincatum: Avranches

4. Civitas Ebroicorum: Evreux

5. Civitas Saiorum: Séez

6. Civitas Lexoviorum: Lisieux

7. Givitas Constantia: Coutances (Cotentin)

\section{Lugdunensis Tertia}

1. Metropolis civitas Turonorum: Tours (Touraine)

2. Civitas Cenomannorum: Le Mans (Maine)

3. Civitas Redonum: Rennes

4. Civitas Andecavorum: Angers (Anjou)

5. Civitas Namnetum: Nantes

6. Civitas Curiosolitum: Corseul 
7. Givitas Venetum: Vannes

8. Givitas Dolensium: Dol

D. Lugdunensis Senonia

1. Metropolis civitas Senonum: Sens

2. Civitas Carnotum: Chartres

3. Givitas Autisioderum: Auxerre

4. Civitas Tricassium: Troyes

5. Givitas Aurelianorum: Orleans

6. Civitas Parisiorum: Paris

7. Givitas Melduorum: Meaux

8. Givitas Nivernensium: Nevers

E. Belgica Prima

1. Metropolis civitas Treverorum: Trier

2. Givitas Mediomatricum: Metz

3. Civitas Leucorum: Toul

4. Civitas Verodunensium: Verdun

F. Belgica Secunda

1. Metropolis civitas Remorum: Rheims

2. Civitas Suessionum: Soissons

3. Civitas Catalaunorum: Châlons-sur-Marne

4. Civitas Veromandorum: Vermand

5. Civitas Atrebatum: Arras (Artois)

6. Civitas Camaracensium: Cambrai

7. Civitas Turnacensium: Tournai

8. Givitas Silvanectum: Senlis

9. Civitas Bellovacorum: Beauvais

10. Givitas Ambianensium: Amiens

11. Civitas Morinarum: Thérouanne

12. Givitas Bononiensium: Boulogne

13. Civitas Lugduni Clavati: Laon 


\section{G. Germania Prima}

1. Metropolis civitas Magontiacensium: Mainz

2. Civitas Argentoratensium (Stratoburgensis): Strasbourg

3. Civitas Nemetum (Spirensis): Speyer

4. Civitas Vangionum (Vuormiacensis): Worms

\section{H. Germania Secunda}

1. Metropolis civitas Agrippinensium, Colonia: Cologne

2. Givitas Tungrorum: Tongres

\section{Maxima Sequanorum}

1. Metropolis civitas Vesontiensium: Besançon

2. Civitas Belisensium: Belley

3. Civitas Elvitiorum, Aventicus: Avenches

4. Civitas Basiliensium: Basel

$$
\text { J. Viennensis }
$$

1. Metropolis civitas Viennensium: Vienne

2. Civitas Genavensium: Geneva

3. Givitas Gratianopolitana: Grenoble

4. Civitas Albensium/Vivarium: Aps/Viviers

5. Givitas Deensium: Die

6. Civitas Valentinorum: Valence

7. Givitas Valensium/Sedunensis: Wallis/Sitten

8. Givitas Tarantensium: Tarantaise

9. Civitas Mauriennensis: Maurienne

10. Civitas Augusta: Aosta

\section{K. Aquitanica Prima}

1. Metropolis civitas Biturigum: Bourges (Berry)

2. Civitas Arvernorum: Clermont (-Ferrand) (Auvergne)

3. Civitas Rutenorum: Rodez (Rouergue)

4. Civitas Albigensium: Albi

5. Civitas Cadurcorum: Cahors (Quercy) 
6. Givitas Lemovicum: Limoges (Limousin)

7. Givitas Gabalum:Javols/Mende

8. Civitas Vellavorum: St-Paulien/Le Puy (Velay)

9. Civitas Tolosatium: Toulouse

\section{Aquitanica Secunda}

1. Metropolis civitas Burdigalensium: Bordeaux

2. Civitas Agennensium: Agen

3. Civitas Ecolisnensium: Angoulême (Angoumois)

4. Civitas Santonum: Saintes (Saintonge)

5. Civitas Pictavum: Poitiers (Poitou)

6. Givitas Petrocoriorum: Périgueux (Périgord)

\section{Novempopulana}

1. Metropolis civitas Elusatium: Eauze

2. Givitas Ausciorum: Auch

3. Civitas Aquensium: Dax

4. Civitas Lactoratium: Lectoure

5. Civitas Convenarum: St-Bertrand-de-Comminges

6. Civitas Consorannorum: St-Lizier (Couserans)

7. Civitas Benarnensium: Lescar (Béarn)

8. Civitas Aturensium: Aire

9. Civitas Vasatica: Bazas

10. Civitas Turba ubi castrum Bigorra: Cieutat (Bigorre)

11. Civitas Illoronensium: Oloron

\section{N. Narbonensis Prima}

1. Metropolis civitas Narbonensium: Narbonne

2. Civitas Biterrensium: Béziers

3. Civitas Agatensium: Agde

4. Civitas Magalonensium: Maguelonne

5. Civitas Nemausensium: Nîmes

6. Civitas Lotevensium: Lodève

7. Civitas Elnensium: Elne

8. Civitas Carcassonensium: Carcassonne 


\section{O. Narbonensis Secunda, Alpes Maritimarum, parts of Viennensis}

1. Civitas Arelatensium: Arles

2. Civitas Aquensium: Aix-en-Provence

3. Civitas Aptensium: Apt

4. Civitas Reiensium: Riez

5. Civitas Foroiuliensis: Fréjus

6. Civitas Vappincensium: Gap

7. Civitas Segesteriorum: Sisteron

8. Civitas Antipolitana: Antibes

9. Civitas Ebrodunensium: Embrun

10. Civitas Diniensium: Digne

11. Givitas Telonensium: Toulon

12. Civitas Saniensium: Sénez

13. Civitas Glannativa: Glandève

14. Civitas Cemelensium/Nicea: Cimiez/Nice

15. Civitas Vencensis: Vence

16. Civitas Tricastinorum: St-Paul-Trois-Châteaux

17. Civitas Vasiensium: Vaison

18. Civitas Arausicorum: Orange

19. Civitas Carpentoratensium/Vindascensis: Carpentras/ Vénasque

20. Civitas Cabellicorum: Cavaillon

21. Civitas Avennicorum: Avignon

22. Civitas Massiliensium: Marseilles

23. Civitas Uticensium: Uzès 


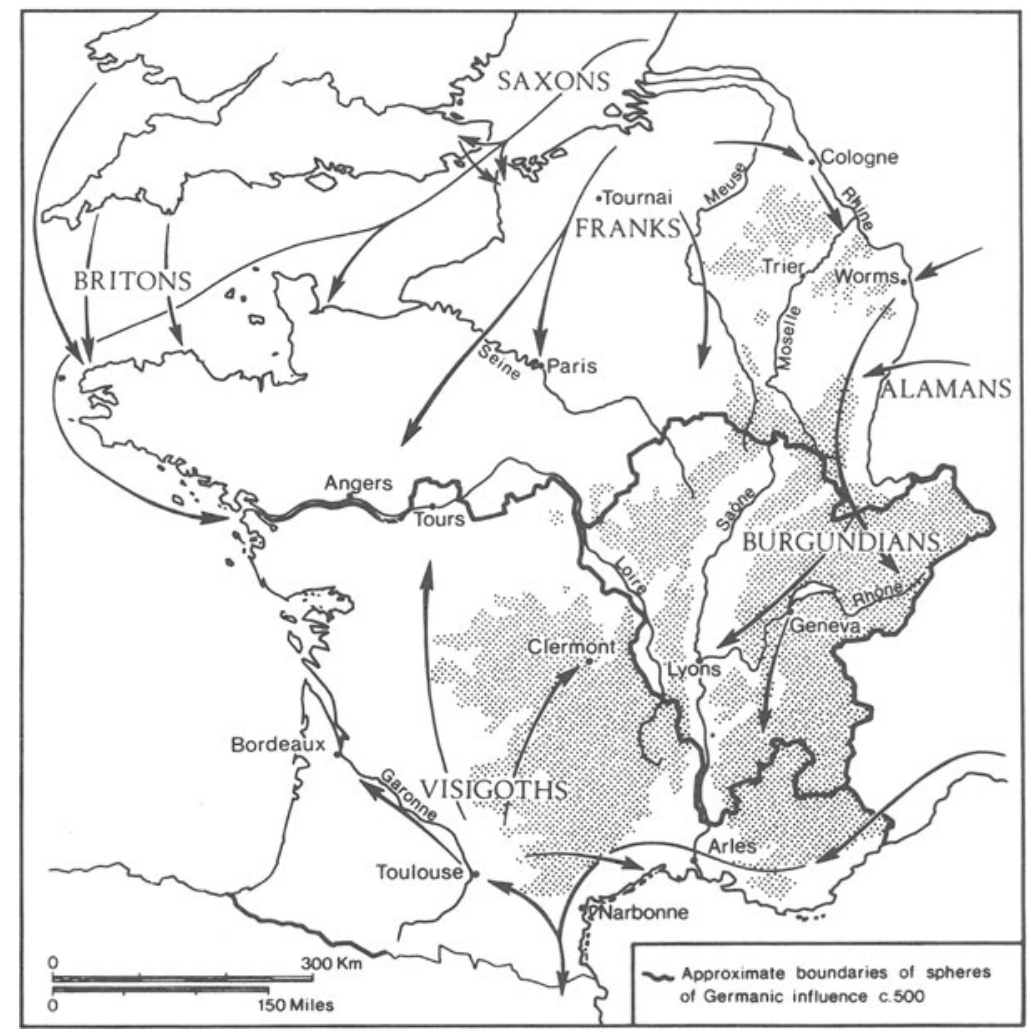

Map 1

Gaul in the Fifth Century 


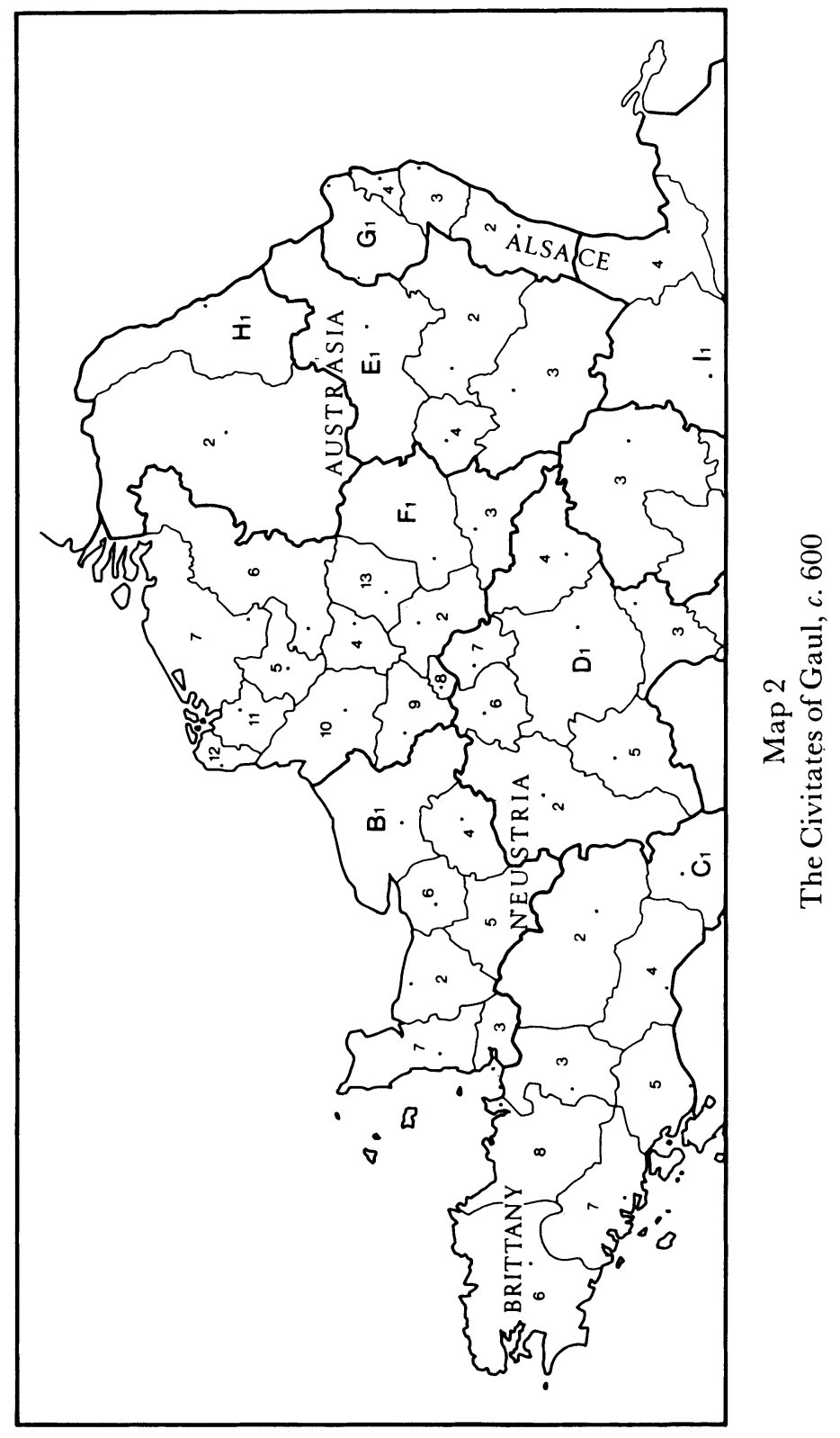




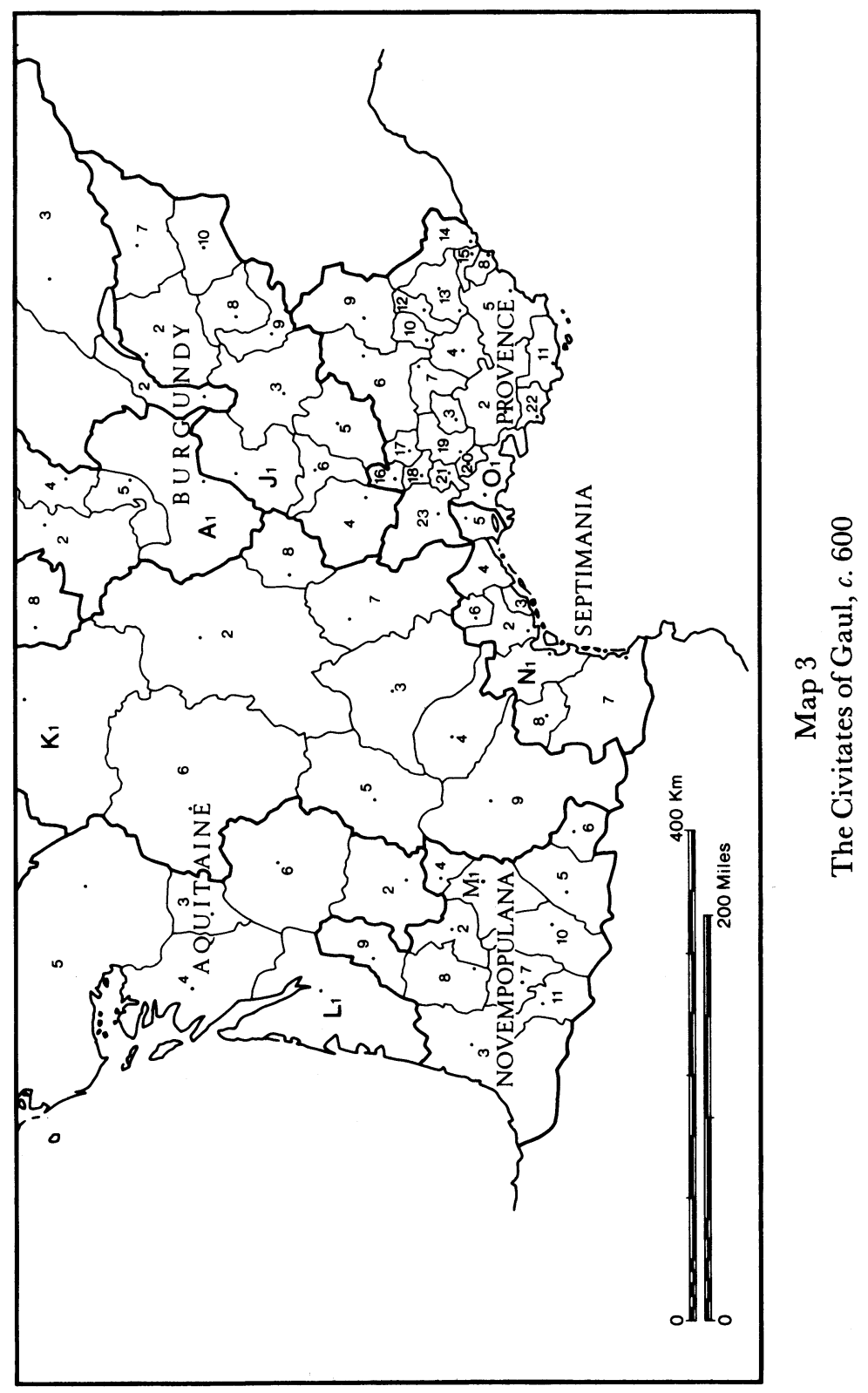




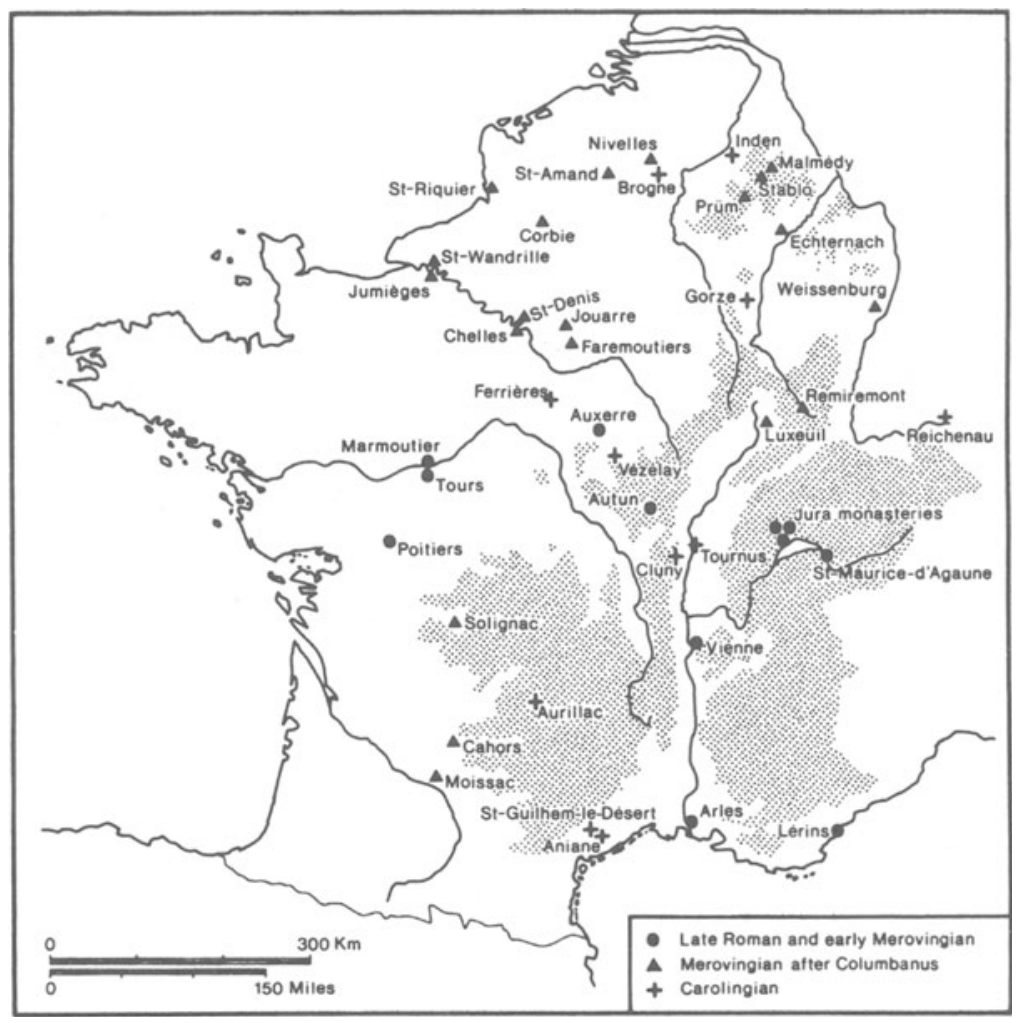

Map 4

The Monasteries of Frankish Gaul 

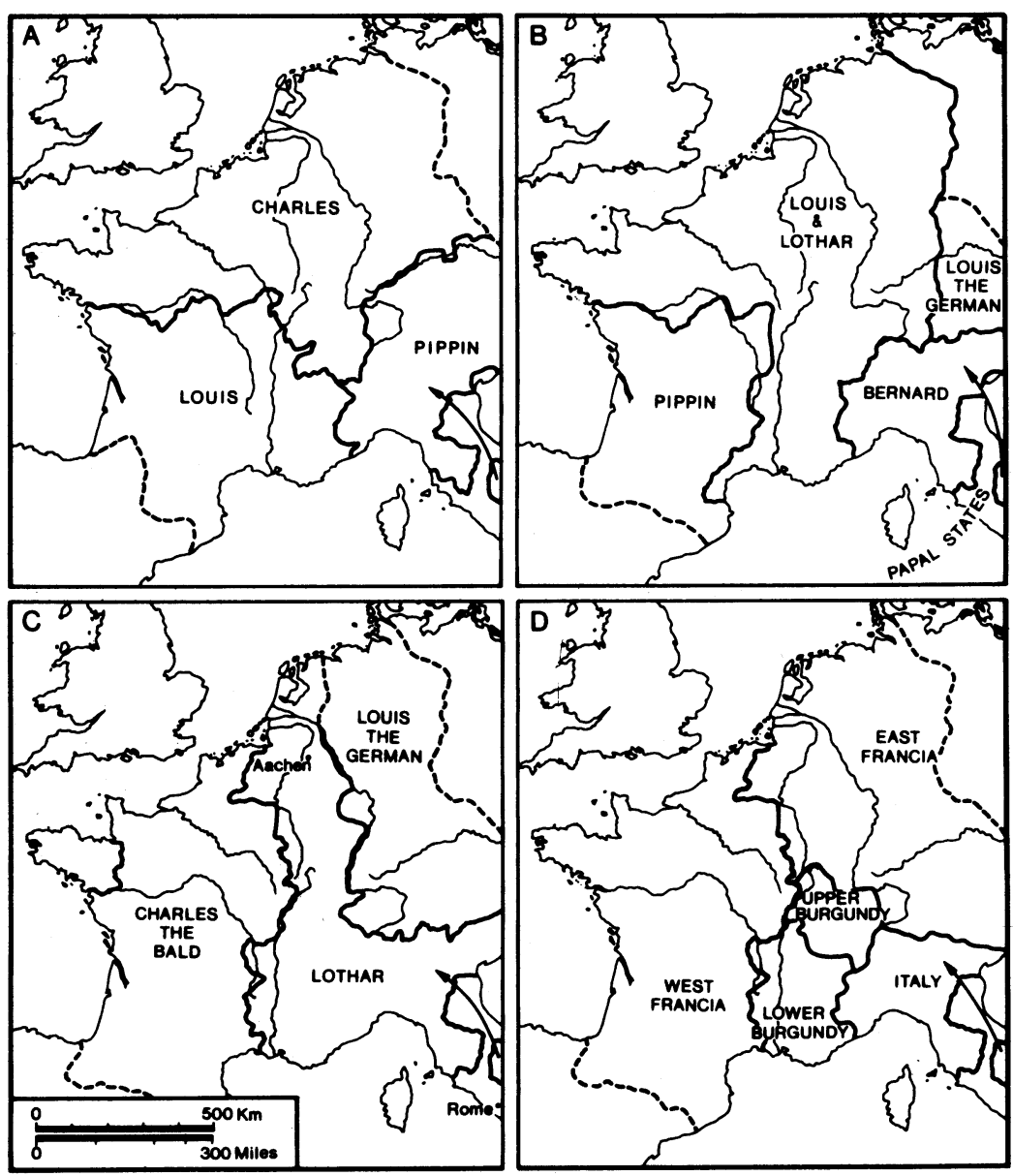

\section{Map 5}

The Partitions of the Ninth Century.

A. The proposed partition of 806 .

B. The divisions of the Ordinatio Imperii, 817.

C. The partition of the Treaty of Verdun, 843.

D. The kingdoms after 888 . 


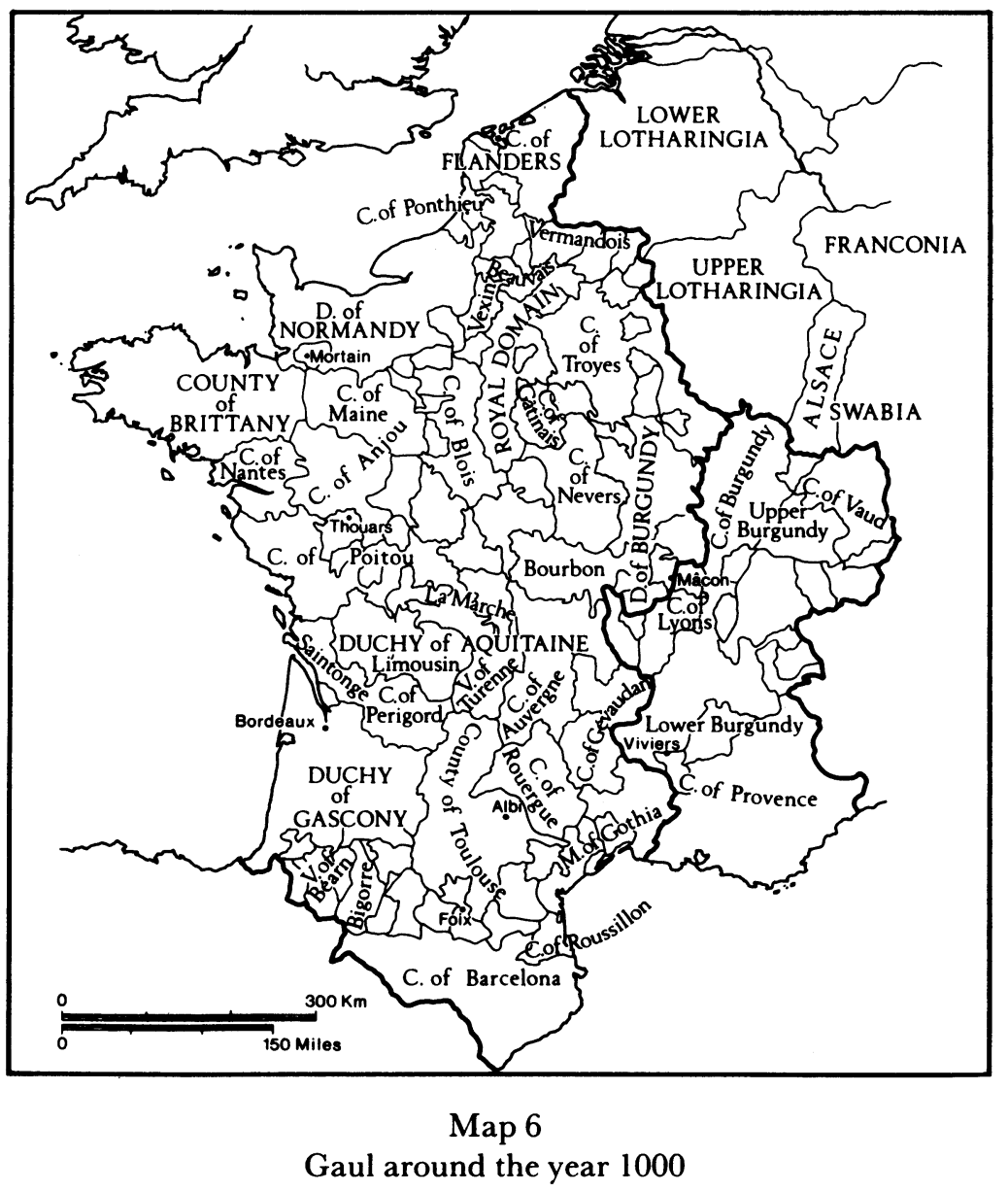

xxiii 